\title{
Confirming Pathogenicity of the F386L PSEN1 Variant in a South Asian Family With Early-Onset Alzheimer Disease
}

Sarah J. Eger, BA, * Yann Le Guen, PhD,* Raiyan R. Khan, BS, Jacob N. Hall, MD, Gabriel Kennedy, BS, Greg Zaharchuk, MD, PhD, Julien Couthouis, PhD, William S. Brooks, MBBS,

Dennis Velakoulis, MBBS, FRANZCP, Valerio Napolioni, PhD, Michaël E. Belloy, PhD, Clifton L. Dalgard, PhD, Elizabeth C. Mormino, PhD, Aaron D. Gitler, PhD, and Michael D. Greicius, MD, MPH

Neurol Genet 2022;8:e647. doi:10.1212/NXG.0000000000000647

\section{Abstract}

\section{Objectives}

The F386L PSEN1 variant has been reported in 1 Japanese family with limited clinical information. We aimed to prove that $\mathrm{F} 386 \mathrm{~L}$ is pathogenic by demonstrating that it segregates with early-onset Alzheimer disease $(\mathrm{AD})$.

\section{Methods}

Eight individuals in a South Asian family provided DNA for genetic testing and underwent a neurologic examination.

\section{Results}

The female proband was diagnosed with $\mathrm{AD}$ at age 45 years and died at age 49 years. She had a CSF biomarker profile consistent with $\mathrm{AD}$, and her florbetaben $\mathrm{PET}$ scan was amyloid positive with high uptake in the striatum. Her MRI showed no prominent white matter disease. Her affected relatives had an age at onset range of 38-57 years and had imaging and biomarker profiles similar to hers.

\section{Discussion}

The results presented here, in conjunction with the prior report, confirm the pathogenicity of F386L. Furthermore, our study highlights the importance of studying families from underrepresented populations to identify or confirm the pathogenicity of rare variants that may be specific to certain genetic ancestries.

\author{
Correspondence \\ Sarah J. Eger \\ eger@ucsb.edu
}

*These authors contributed equally to this work

From the Department of Neurology and Neurological Sciences, Stanford University School of Medicine, Stanford, CA, (S.J.E., Y.L.G., G.K., M.E.B., E.C.M., M.D.G.); Department of Computer Science, Columbia University, New York, NY (R.R.K.) the Neurology Center of Southern California, Temecula, CA (J.N.H.); Department of Radiology, Stanford University School of Medicine, Stanford, CA (G.Z.) Department of Genetics, Stanford University School of Medicine, Stanford, CA (I.C., A.D.G.): Neuroscience Research Australia, Randwick NSW 2031, Australia (W.S.B); the University of New South Wales, Sydney NSW 2052, Australia (W.S.B.); Neuropsychiatry Unit, Royal Melbourne Hospital, Parkville VIC 3050, Australia (D.V.); School of Biosciences and Veterinary Medicine, University of Camerino, Camerino, Italy (V.N); Department of Anatomy, Physiology \& Genetics, Uniformed Services University of the Health Sciences, Bethesda, MD (C.L.D.); the American Genome Center, Uniformed Services University of the Health Sciences, Bethesda, MD (C.L.D.).

The Article Processing Charge was funded by the authors

Go to Neurology.org/NG for full disclosures. Funding information is provided at the end of the article.

This is an open access article distributed under the terms of the Creative Commons Attribution-NonCommercial-NoDerivatives License 4.0 (CC BY-NC-ND), which permits downloading and sharing the work provided it is properly cited. The work cannot be changed in any way or used commercially without permission from the journal. 
Alzheimer disease (AD) primarily affects individuals older than 65 years, but autosomal dominant variants in presenilin-1 (PSEN1) have been found to cause early-onset AD (EOAD). ${ }^{1}$ The missense PSEN1 variant $\mathrm{c} .1158 \mathrm{C}>\mathrm{A}$, which substitutes a leucine for a phenylalanine at codon 386 (p.F386L), has been reported in 2 Japanese siblings with EOAD. ${ }^{2}$ We provide definitive pathogenic evidence for F386L in a large family originally from the southeastern coastal state Andhra Pradesh in India.

\section{Methods and Results}

The proband (III-24, Figure 1) was a woman whose memory began declining at age 44 years. Her early symptoms included repeating questions and leaving the stove on and the refrigerator door open, followed by word-finding difficulty and visuospatial issues requiring her to stop driving. At age 45 years, she was diagnosed with $\mathrm{AD}$. On examination, she demonstrated phonemic paraphasic errors, difficulty following complex commands, slight symmetric cogwheeling at the wrists, mildly increased lower extremity tone, brisk patellar reflexes, slightly unstable gait, decreased left arm swing, and postural instability with retropulsion. She scored 13/30 on the Mini-Mental State Examination (MMSE). Florbetaben PET/MRI scan revealed prominent posterior parietal and medial temporal atrophy, no substantial white matter hyperintensities, and high tracer uptake in the striatum (Figure 2A). Her PET scan was amyloid positive. Her CSF biomarker profile, performed by Athena Diagnostics, was consistent with $\mathrm{AD}(\mathrm{A} \beta-42=296 \mathrm{pg} / \mathrm{mL}$, t-tau $=617 \mathrm{pg} /$ $\mathrm{mL}, \mathrm{p}$-tau $=96 \mathrm{pg} / \mathrm{mL}$, and amyloid tau index $=0.31)$; Athena only provides cutoffs for p-tau (abnormal above $68 \mathrm{pg} / \mathrm{mL}$ ) and the amyloid tau index (abnormal below 0.8). She died at age 49 years. Clinical genetic testing confirmed that she carried F386L. Her mother and uncle (II-6, II-7; Figure 1) were diagnosed with dementia in their forties and died in their fifties but did not undergo genetic testing. Three additional family members carried F386L. The younger sister (III-25, Figure 1) was diagnosed with $\mathrm{AD}$ at age 43 years after presenting with progressive memory impairment for 1-2 years followed by trouble with executive function. She scored $10 / 30$ on the Montreal Cognitive Assessment. Her neurologic examination was otherwise normal. The female cousin (III-26, Figure 1) began misplacing items, became dependent on writing things down, and was leaving the stove on at age 38 years. She became disoriented in her own neighborhood, was missing appointments, and was asked to resign from her job at age 41 years. She scored 24/30 on the MMSE. CSF showed reduced A $\beta-42$, elevated total tau, and elevated phospho-tau. MRI showed mild, symmetric frontoparietal atrophy, and SPECT showed frontal and mediotemporal hypoperfusion. At age 43 years, she scored 14/30 on the MMSE, developed left-sided parkinsonism with increased tone, reduced reflexes, intermittent upper extremity myoclonic jerks, and polyminimyoclonus. She died at age 45 years. The male cousin (III-39, Figure 1) was cognitively unimpaired at age 36 years and had a normal neurologic examination. His florbetaben PET scan was amyloid positive and showed pronounced striatal uptake (Figure 2B, see also eFigure 1, links.lww. com/NXG/A504). On neurological examination, the proband's 54-year-old older sister, 76-year-old aunt, 66-year-old female cousin, and 46-year-old female cousin (III-22, II-12, III-19, and III-27, respectively; Figure 1) were cognitively normal, and none carried F386L.

\section{Standard Protocol Approvals, Registrations, and Patient Consents}

The Stanford Institutional Review Board (IRB00004593) and the Melbourne Health Human Research Ethics Committee (2013.295) approved the study. We obtained informed consent and consent to disclose from participants (or their caregivers).

Figure 1 Family Pedigree Demonstrating F386L Segregates With Early-Onset AD

।

II

III

$$
0
$$
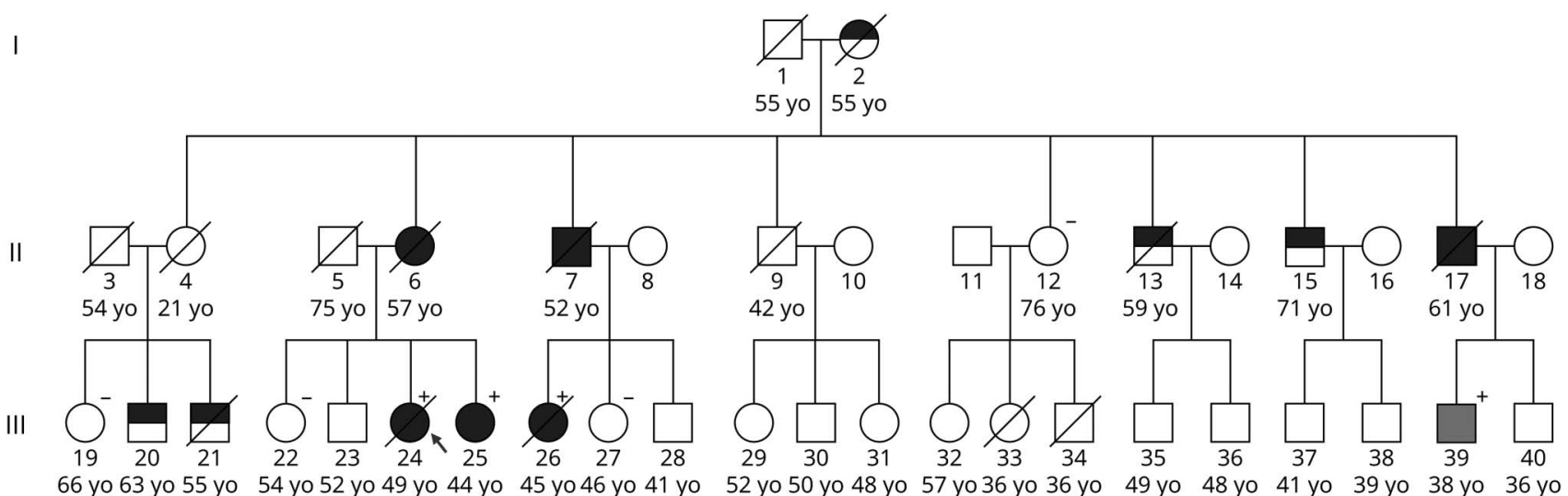

III-24 (arrow) is the proband. III-39 (gray symbol) is cognitively normal but amyloid PET positive. A solid black symbol indicates that the individual was either clinically diagnosed with AD by the authors or the family provided sufficient medical record detail of the diagnosis. A half-black symbol indicates that the individual was suspected by the family to have been affected but was not formally diagnosed. Additional clinical and anecdotal information is included in eAppendix 2, links. Iww.com/NXG/A504. Plus (+) and minus (-) signs indicate F386L carrier or noncarrier status (genetic testing described in eAppendix 3, links. Iww.com/NXG/A504). Females are depicted as circles and males as squares. Ages represent age at death (for those marked as deceased with a diagonal line through the symbol) or current age. 



(A) The proband's FLAIR images (first row) demonstrate only trace periventricular white matter changes. The florbetaben PET images (second row) are positive for cortical amyloid and show prominent amyloid deposition in the striatum. The brainstem was used as the reference region for the standardized uptake value ratios (SUVRs). (B) The unaffected male cousin's FLAIR images (third row) are normal. His florbetaben PET images (fourth row) are positive and display similar striatal deposition to (A) that is not seen in older unrelated noncarriers (see eAppendix 4, links. Iww.com/NXG/A504).

\section{Data Availability}

Anonymized data not published here will be made available by request from any qualified investigator.

\section{Discussion}

In addition to F386S and F386I (see eAppendix 1, links. lww.com/NXG/A504), we have shown that F386L is also pathogenic. We report initial symptoms and an age at onset range of 38-57 years, comparable to the Japanese siblings. ${ }^{2}$ In this family, we note a fairly wide variability of disease duration (ranging from 4 to $19+$ years). The proband (III-24) and male cousin (III-39) showed high striatal amyloid deposition, typical of some PSEN1 variant carriers. ${ }^{3}$ Their lack of prominent early motor symptoms supports the growing consensus that regional amyloid plaque has little to no bearing on 
regional dysfunction. ${ }^{4,5}$ None of the carriers with MRI scans (III-24, III-26, and III-39) had significant white matter involvement, which is inconsistent with the hypothesis that PSEN1 variants beyond codon 200 increase predisposition to leukoencephalopathy. ${ }^{6}$ We were unable to sequence DNA from any second-generation cases. We have shown that F386L segregates with disease (and/or amyloid positivity) in 8 individuals ( 3 affected, 1 unaffected but amyloid positive, and 4 unaffected) in a pedigree with autosomal dominant EOAD. In searching for other reported PSEN1 variants detected in Indian ancestry families, we found 1 additional study, ${ }^{7}$ emphasizing the need to expand the ancestral diversity of genetic research.

\section{Study Funding}

This study was provided by the National Institutes of Health (AG060747 and AG047366) and the Iqbal Farrukh and Asad Jamal Fund.

\section{Disclosure}

The authors report no disclosures relevant to the manuscript. Go to Neurology.org/NN for full disclosures.

\section{Publication History}

Received by Neurology: Genetics August 12, 2021. Accepted in final form October 20, 2021.

Appendix Authors

\begin{tabular}{lll}
\hline Name & Location & Contribution \\
\hline Sarah J. Eger, & Department of Neurology & Drafting/revision of the \\
BA & $\begin{array}{l}\text { and Neurological Sciences, } \\
\text { Stanford University School } \\
\text { of Medicine, Stanford, CA }\end{array}$ & $\begin{array}{l}\text { including medical writing for } \\
\text { content; major role in the } \\
\text { acquisition of data; and } \\
\text { analysis or interpretation of } \\
\text { data }\end{array}$ \\
& & \\
& &
\end{tabular}

\begin{tabular}{ll}
\hline Yann Le & Department of Neurology \\
Guen, PhD & and Neurological Sciences, \\
& Stanford University School \\
& of Medicine, Stanford, CA
\end{tabular}

Drafting/revision of the manuscript for content, including medical writing for content; major role in the acquisition of data; and analysis or interpretation of data

\begin{tabular}{ll}
\hline Raiyan R. & Department of Computer \\
Khan, BS & Science, Columbia \\
& University, New York, NY
\end{tabular}

Drafting/revision of the manuscript for content, including medical writing for content; major role in the acquisition of data; and analysis or interpretation of data

\begin{tabular}{ll}
\hline Jacob N. Hall, & The Neurology Center of \\
MD & Southern California, \\
& Temecula, CA
\end{tabular}

Drafting/revision of the manuscript for content, including medical writing for content, and major role in the acquisition of data

\begin{tabular}{lll}
\hline $\begin{array}{l}\text { Gabriel } \\
\text { Kennedy, BS }\end{array}$ & $\begin{array}{l}\text { Department of Neurology } \\
\text { and Neurological Sciences, } \\
\text { Stanford University School } \\
\text { of Medicine, Stanford, CA }\end{array}$ & $\begin{array}{l}\text { Drafting/revision of the } \\
\text { manuscript for content, } \\
\text { including medical writing for } \\
\text { content, and analysis or } \\
\text { interpretation of data }\end{array}$ \\
\hline
\end{tabular}

Appendix (continued)

\begin{tabular}{|c|c|c|}
\hline Name & Location & Contribution \\
\hline $\begin{array}{l}\text { Greg } \\
\text { Zaharchuk, } \\
\text { MD, PhD }\end{array}$ & $\begin{array}{l}\text { Department of Radiology, } \\
\text { Stanford University School } \\
\text { of Medicine, Stanford, CA }\end{array}$ & $\begin{array}{l}\text { Drafting/revision of the } \\
\text { manuscript for content, } \\
\text { including medical writing for } \\
\text { content, and analysis or } \\
\text { interpretation of data }\end{array}$ \\
\hline $\begin{array}{l}\text { Julien } \\
\text { Couthouis, } \\
\text { PhD }\end{array}$ & $\begin{array}{l}\text { Department of Genetics, } \\
\text { Stanford University School } \\
\text { of Medicine, Stanford, CA }\end{array}$ & $\begin{array}{l}\text { Drafting/revision of the } \\
\text { manuscript for content, } \\
\text { including medical writing for } \\
\text { content, and analysis or } \\
\text { interpretation of data }\end{array}$ \\
\hline $\begin{array}{l}\text { William S. } \\
\text { Brooks, } \\
\text { MBBS }\end{array}$ & $\begin{array}{l}\text { Neuroscience Research } \\
\text { Australia, Randwick NSW } \\
\text { 2031, The University of New } \\
\text { South Wales, Sydney NSW } \\
\text { 2052, Australia }\end{array}$ & $\begin{array}{l}\text { Drafting/revision of the } \\
\text { manuscript for content, } \\
\text { including medical writing for } \\
\text { content; major role in the } \\
\text { acquisition of data; and } \\
\text { analysis or interpretation of } \\
\text { data }\end{array}$ \\
\hline
\end{tabular}

Dennis Neuropsychiatry Unit, Royal Drafting/revision of the

Velakoulis, Melbourne Hospital, manuscript for content,

MBBS, Parkville VIC 3050, Australia including medical writing for

FRANZCP content; major role in the

acquisition of data; and analysis or interpretation of data

\begin{tabular}{ll}
\hline Valerio & School of Biosciences and \\
Napolioni, & Veterinary Medicine, \\
PhD & University of Camerino, \\
& Camerino, Italy
\end{tabular}

Drafting/revision of the manuscript for content, including medical writing for content

Michaël E. Department of Neurology

Belloy, PhD and Neurological Sciences, Stanford University School of Medicine, Stanford, CA

Drafting/revision of the manuscript for content including medical writing for content

\begin{tabular}{|c|c|c|}
\hline $\begin{array}{l}\text { Clifton L. } \\
\text { Dalgard, PhD }\end{array}$ & $\begin{array}{l}\text { Department of Anatomy, } \\
\text { Physiology \& Genetics, } \\
\text { Uniformed Services University } \\
\text { of the Health Sciences, The } \\
\text { American Genome Center, } \\
\text { Uniformed Services University } \\
\text { of the Health Sciences, } \\
\text { Bethesda, MD }\end{array}$ & $\begin{array}{l}\text { Drafting/revision of the } \\
\text { manuscript for content, } \\
\text { including medical writing for } \\
\text { content }\end{array}$ \\
\hline
\end{tabular}

Elizabeth C. Department of Neurology Mormino, and Neurological Sciences, PhD Stanford University School of Medicine, Stanford, CA

Drafting/revision of the manuscript for content, including medical writing for content; major role in the acquisition of data; and analysis or interpretation of data

\begin{tabular}{lll}
\hline $\begin{array}{l}\text { Aaron D. } \\
\text { Gitler, PhD }\end{array}$ & $\begin{array}{l}\text { Department of Genetics, } \\
\text { Stanford University School } \\
\text { of Medicine, Stanford, CA }\end{array}$ & $\begin{array}{l}\text { Drafting/revision of the } \\
\text { manuscript for content, } \\
\text { including medical writing for } \\
\text { content, and analysis or } \\
\text { interpretation of data }\end{array}$ \\
\hline $\begin{array}{l}\text { Michael D. } \\
\text { Greicius, MD, } \\
\text { MPH }\end{array}$ & $\begin{array}{l}\text { Department of Neurology } \\
\text { Stanford University School } \\
\text { of Medicine, Stanford, CA }\end{array}$ & $\begin{array}{l}\text { Drafting/revision of the } \\
\text { manuscript for content, } \\
\text { including medical writing for } \\
\text { content; major role in the } \\
\text { acquisition of data; study } \\
\text { concept or design; and } \\
\text { analysis or interpretation of } \\
\text { data }\end{array}$ \\
& &
\end{tabular}

\section{References}

1. Sherrington R, Rogaev EI, Liang Y, et al. Cloning of a gene bearing missense mutations in early-onset familial Alzheimer's disease. Nature. 1995;375(6534): 754-760. 
2. Yagi R, Miyamoto R, Morino H, et al. Detecting gene mutations in Japanese Alzheimer's patients by semiconductor sequencing. Neurobiol Aging. 2014;35(7):1780e1-1780e5.

3. Klunk WE, Price JC, Mathis CA, et al. Amyloid deposition begins in the striatum of presenilin1 mutation carriers from two unrelated pedigrees. J Neurosci. 2007;27(23):6174-6184

4. Altmann A, Ng B, Landau SM, Jagust WJ, Greicius MD. Regional brain hypometabolism is unrelated to regional amyloid plaque burden. Brain. 2015;138(12): 3734-3746.
5. Ossenkoppele R, Schonhaut DR, Schöll M, et al. Tau PET patterns mirror clinical and neuroanatomical variability in Alzheimer's disease. Brain. 2016;139(5):1551-1567.

6. Ryan NS, Biessels GJ, Kim L, et al. Genetic determinants of white matter hyperintensities and amyloid angiopathy in familial Alzheimer's disease. Neurobiol Aging. 2015;36(12):3140-3151.

7. Syama A, Sen S, Kota LN, et al. Mutation burden profile in familial Alzheimer's disease cases from India. Neurobiol Aging. 2018;64:158e 7-158e13. 


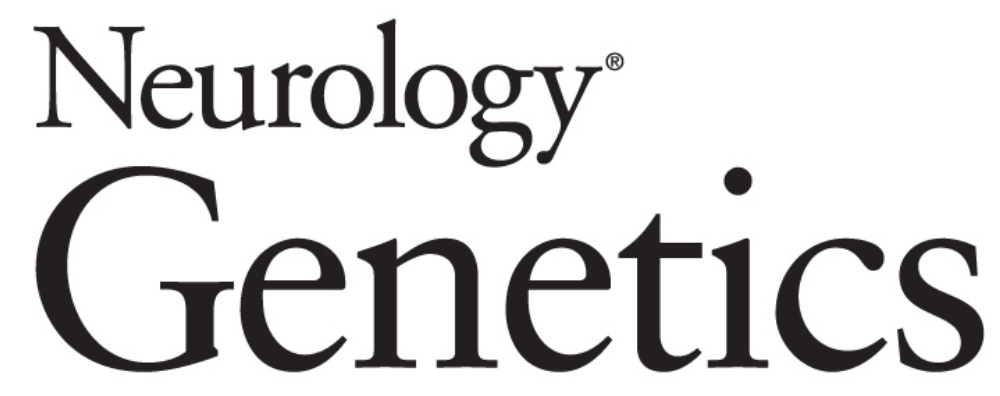

Confirming Pathogenicity of the F386L PSEN1 Variant in a South Asian Family With
Early-Onset Alzheimer Disease

Sarah J. Eger, Yann Le Guen, Raiyan R. Khan, et al.

Neurol Genet 2022;8;

DOI 10.1212/NXG.0000000000000647

This information is current as of December 7, 2021

\section{Updated Information \&} Services

References

Subspecialty Collections

Permissions \& Licensing

Reprints including high resolution figures, can be found at: http://ng.neurology.org/content/8/1/e647.full.html

This article cites 7 articles, 1 of which you can access for free at: http://ng.neurology.org/content/8/1/e647.full.html\#\#ref-list-1

This article, along with others on similar topics, appears in the following collection(s):

Alzheimer's disease

http://ng.neurology.org//cgi/collection/alzheimers_disease PET

http://ng.neurology.org//cgi/collection/pet

Information about reproducing this article in parts (figures,tables) or in its entirety can be found online at:

http://ng.neurology.org/misc/about.xhtml\#permissions

Information about ordering reprints can be found online: http://ng.neurology.org/misc/addir.xhtml\#reprintsus

Neurol Genet is an official journal of the American Academy of Neurology. Published since April 2015, it is an open-access, online-only, continuous publication journal. Copyright Copyright $\odot 2021$ The Author(s). Published by Wolters Kluwer Health, Inc. on behalf of the American Academy of Neurology.. All rights reserved. Online ISSN: 2376-7839.

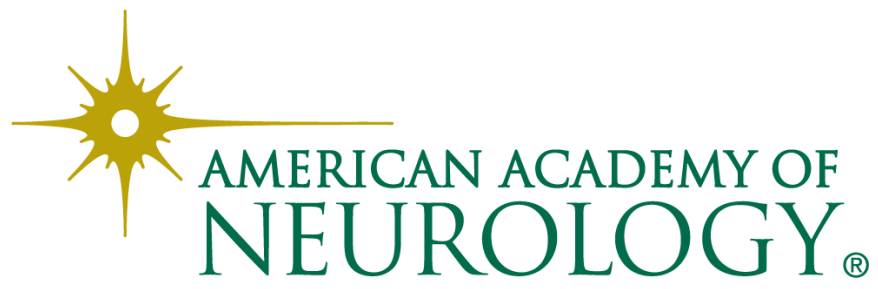

